\title{
Copper-dependent and Iron-dependent Inactivations of Cucumber Mosaic Virus by Polyphenols
}

\author{
By W. S. PIERPOINT AND B. D. HARRISON \\ Rothamsted Experimental Station, Harpenden, Hertfordshire
}

(Received 15 March 1963)

\begin{abstract}
SUMMARY
Extracts made by crushing infected tobacco leaves in buffer solution containing sodium diethyldithiocarbamate (DIECA), centrifuging at $8000 \mathrm{~g}$, and dialysing the supernatant fluids against dilute buffer, were used to study the inactivation of cucumber mosaic virus (CMV). Incubating such extracts with chlorogenic acid and copper inactivated them; inactivation was usually much less when they were incubated with chlorogenic acid alone. Inactivation did not occur in vacuo or when DIECA was added. DIECA did not reactivate inactivated virus. CMV was inactivated rapidly by incubating with caffeic acid and copper, and slowly with catechol and copper, but not with five other phenols. The end-products of oxidation formed when chlorogenic acid was incubated with extracts of uninfected leaves did not inactivate CMV. Some features of the CMVinactivating system are explained by the properties of tobacco leaf polyphenoloxidase. The compounds most effective in preserving the infectivity of CMV during extraction from leaves, DIECA and potassium ethylxanthate, are those which most strongly inhibit the enzyme. Conversely, the polyphenols that inactivate $\mathrm{CMV}$ in vitro are those oxidized most rapidly. Inconsistent effects of copper on the in vitro inactivating system can be partly explained by the different copper requirement of the polyphenoloxidase in extracts from plants infected for different times. Iron salts also accelerate the inactivation of CMV by chlorogenic acid. The process requires air and is prevented by DIECA; iron did not reactivate the DIECA-inhibited polyphenoloxidase. This system seems different from the one stimulated by copper. The concentration of iron in leaf extracts is usually less than that needed by the inactivating system.
\end{abstract}

\section{INTRODUCTION}

Stable extracts of cucumber mosaic virus (CMV) can be prepared by grinding infected tobacco leaves in the presence of sodium diethyldithiocarbamate (DIECA) or potassium ethylxanthate, centrifuging at low speed, and then dialysing overnight against dilute buffer (Harrison \& Pierpoint, 1963). DIECA and potassium ethylxanthate also prevent the browning of leaf extracts, probably by inhibiting the oxidation of leaf polyphenols by leaf polyphenoloxidase, an enzyme thought to contain copper. We therefore suggested that CMV was inactivated by some product of polyphenol oxidation, and that the virus was stable in these leaf extracts because the enzyme was inhibited and the polyphenol substrates dialysed away. When infective extracts were incubated with chlorogenic acid or deproteinized extracts made anaerobically from tobacco leaves, and copper was added to reactivate the polyphenoloxidase, CMV was inactivated. The in vitro inactivation of CMV by 
chlorogenic acid and copper salts is the subject of the present paper. The oxidation of polyphenols by leaf polyphenoloxidase was studied manometrically to see how far the properties of the enzyme might account for those of the virus-inactivating system.

\section{METHODS}

Leaf extracts. Cucumber mosaic virus (CMV) preparations were made with the aid of DIECA from infected tobacco leaves as described by Harrison \& Pierpoint (1963); they will be referred to as infective extracts. Extracts of uninfected leaves were also made in this manner except that the amount of extraction medium used was usually 2-3 ml./g. leaf material.

Extracts required for metal determinations were made from infected leaves using either water or tris $\mathrm{HCl}$ buffer $(0 \cdot 2 \mathrm{M} ; \mathrm{pH} 7 \cdot 8)$. Most of the protein was removed by adjusting to $\mathrm{pH} 5$ with $\mathrm{HCl}$, and centrifuging; the supernatant fluid was then evapoted to dryness. Iron and copper in the residue were estimated spectroscopically.

Virus inactivation. Eight $\mathrm{ml}$. of reaction mixture contained $5 \mathrm{ml}$. infective extract, 2-amino-2-(hydroxymethyl)-1,3-propanediol (tris) buffer (50 $\mathrm{mm}$; pH 7-1) and, when they were required, chlorogenic acid $(2.6 \mathrm{~mm}$ adjusted to $\mathrm{pH} 7)$ and copper sulphate $(0 \cdot 25 \mathrm{~mm})$. Incubation was either at room temperature (about $\left.18^{\circ}\right)$ or in a water bath at $22^{\circ}$. DIECA dissolved in tris buffer $(0 \cdot 2 \mathrm{M} ; \mathrm{pH} 7 \cdot 8)$ was sometimes added at this stage to stop further inactivation. The incubated solutions were then dialysed for 2-3 hr., or occasionally overnight, against phosphate buffer (about $5 \mathrm{~mm}$; $\mathrm{pH} 7 \cdot 4$ ) before being tested for infectivity.

To incubate in vacuo, the reactants were put into flasks that had ground-glass stoppers with taps. These flasks were divided internally into two shallow compartments by a central ridge. Virus extracts + copper sulphate were put into one of these compartments, and buffer + chlorogenic acid into the other; the two liquids were mixed when the flasks had been evacuated with an oil pump.

Infectivity was assayed as described by Harrison \& Pierpoint (1963). The numbers of lesions given in the Tables are the total that formed in eight or more half-leaves of French bean. When the infectivities of more than six samples were to be compared, the samples were divided into batches, with a standard inoculum included in each batch; in such experiments the numbers of lesions quoted are relative to the number given by the standard inoculum.

Manometric experiments. The oxidation of polyphenols by extracts of tobacco leaves was followed at $30^{\circ}$ in the conventional Warburg apparatus. The centre wells of the flasks contained folded pieces of filter paper and $0.2 \mathrm{ml} .10 \%(\mathrm{w} / \mathrm{v}) \mathrm{KOH}$. Shaking was at the rate of 120 strokes/min., and a $10 \mathrm{~min}$. equilibration period was allowed before the taps were closed. The final concentrations of reagents in the manometer flasks were similar to those in the virus inactivation experiments: phenolic substrate, $3 \cdot 2 \mathrm{~mm}$; copper sulphate, $0.36 \mathrm{~mm}$; tris buffer (pH 7), $70 \mathrm{~mm}$; leaf extract, $1.5 \mathrm{ml}$; final volume usually $2.8 \mathrm{ml}$. The phenols were usually added to the manometer side-arms either as solutions or suspensions at $\mathrm{pH}$ 7. They were tipped into the main compartments after equilibration. Compounds were tested as polyphenoloxidase inhibitors by adding them in solution at $\mathrm{pH} \mathrm{r}$ to the main compartments of manometer flasks. They were therefore incubated with enzyme but without substrate during the equilibration period; absorption of oxygen was 
followed during the next $30 \mathrm{~min}$. In some experiments the carbon dioxide produced during the oxidation was estimated manometrically by the 'direct' method (Umbreit, Burris \& Stauffer, 1957).

\title{
RESULTS
}

\section{Inactivation of CMV by chlorogenic acid and copper}

When extracts containing CMV were incubated with chlorogenic acid + copper salts, infectivity disappeared. Table 1 illustrates this, and also shows that chlorogenic acid was effective at $0 \cdot 1 \mathrm{~mm}$; extracts of infected leaves contain about $0 \cdot 4 \mathrm{~mm}$ (Harrison \& Pierpoint, 1963). The minimum effective concentration of copper differed in different experiments (probably depending on the completeness with which DIECA was dialysed away from the extracts); with one extract the effective copper concentration was $6 \cdot 3 \mu \mathrm{M}$ but with another $250 \mu \mathrm{M}$. In about a third of the extracts examined, CMV was inactivated by chlorogenic acid alone, usually only slightly, but sometimes as much as with added copper.

\section{Table 1. Effect of concentration of chlorogenic acid on the inactivation of $\mathrm{CMV}$}

\begin{abstract}
Samples of infective leaf extract $(5 \mathrm{ml}$.) were added to a series of tubes containing tris buffer (final concentration $50 \mathrm{~mm}$; pH 7), chlorogenic acid and copper sulphate as indicated, and water to $8 \mathrm{ml}$. The solutions were incubated at $18^{\circ}$ for $2 \mathrm{hr}$. then dialysed at $2^{\circ}$ and assayed for infectivity.
\end{abstract}

\begin{tabular}{|c|c|c|}
\hline \multicolumn{2}{|c|}{$\begin{array}{c}\text { Additions } \\
\text { (final concentrations) }\end{array}$} & \multirow[b]{2}{*}{ No. lesions } \\
\hline $\begin{array}{c}\text { Chlorogenic } \\
\text { acid } \\
(\mathrm{mM})\end{array}$ & $\begin{array}{l}\text { Copper } \\
\text { sulphate } \\
\text { (mM) }\end{array}$ & \\
\hline 0 & 0 & 300 \\
\hline 0 & $0 \cdot 19$ & 374 \\
\hline $2 \cdot 6$ & 0 & 240 \\
\hline $2 \cdot 6$ & $0 \cdot 19$ & 11 \\
\hline $1 \cdot 1$ & $0 \cdot 19$ & 4 \\
\hline 0.26 & $0 \cdot 19$ & 10 \\
\hline 0.11 & $0 \cdot 19$ & 46 \\
\hline 0.011 & $0 \cdot 19$ & 338 \\
\hline 0.0011 & $0 \cdot 19$ & 422 \\
\hline
\end{tabular}

DIECA, at five or ten times the molar concentration of copper, almost completely prevented CMV from being inactivated. Adding DIECA after incubating infective extracts with chlorogenic acid + copper did not restore infectivity. It was previously shown that the small amounts of DIECA which might be left in solution after dialysis did not affect infectivity (Harrison \& Pierpoint, 1963). By making use of DIECA to stop the reaction, the time course of the inactivation of CMV was followed and the effect of air studied. Table 2 shows a time course in which inactivation was complete in $45 \mathrm{~min}$. when copper was added; but without copper inactivation was slight after this time. However, after $2 \cdot 5 \mathrm{hr}$., chlorogenic acid alone produced appreciable inactivation. In other experiments done at the same or similar temperatures, CMV was almost completely inactivated with chlorogenic acid + copper in either shorter $(15 \mathrm{~min}$.$) or longer (120 \mathrm{~min}$.$) periods. Table 3$ shows 
the dependence of inactivation on air. In this experiment, the incubation period was long and there was appreciable inactivation without added copper, but this, like inactivation with copper, required air.

\section{Table 2. Time course of inactivation of $C M V$}

Samples of infective leaf extract $(5 \mathrm{ml}$.) were added to a series of solutions containing tris buffer ( $\mathrm{pH} 7$; final concentration $50 \mathrm{~mm}$ ) and either copper sulphate (0.25 mM), chlorogenic acid $(2.6 \mathrm{~mm})$, or both. The final volumes were made up to $8 \mathrm{ml}$. with water and the solutions incubated at $21^{\circ}$. After various times they were cooled, DIECA added (final concentration $1.25 \mathrm{~mm}$ ) and then dialysed at $2^{\circ}$ for at least $3 \mathrm{hr}$. before being assayed for infectivity.

$\begin{array}{cccc}\begin{array}{c}\text { Time of } \\ \text { incubation } \\ \text { (min.) }\end{array} & \begin{array}{c}\text { Copper sulphate } \\ \text { added }\end{array} & \begin{array}{c}\text { Chlorogenic } \\ \text { acid added }\end{array} & \begin{array}{c}\text { Copper sulphate } \\ \text { +chlorogenic } \\ \text { acid added }\end{array} \\ 0 & 200 & 231 & 262 \\ 15 & 133 & 197 & 116 \\ 45 & 120 & 116 & 18 \\ 150 & 136 & 53 & 5\end{array}$

Table 3. The effect of air on the inactivation of $C M V$

Each tube had 4.5 ml. solution containing $3 \mathrm{ml}$. infective extract, tris buffer ( $\mathrm{pH} 7$; final concentration $4.5 \mathrm{~mm})$, copper sulphate $(0.45 \mathrm{~mm})$ and chlorogenic acid $(2.3 \mathrm{~mm})$ as specified below. Some tubes were evacuated immediately and all were kept at room temperature $\left(18^{\circ}\right)$ for $2.5 \mathrm{hr}$. DIECA was then added to all the solutions (final concentration $2 \cdot 2 \mathrm{~mm}$ ) and they were dialysed for $3 \mathrm{hr}$. before being assayed for infectivity.

$\begin{array}{lcc}\begin{array}{c}\text { Additions to } \\ \text { incubation mixture }\end{array} & \begin{array}{c}\text { Incubated } \\ \text { aerobically }\end{array} & \begin{array}{c}\text { Incubated } \\ \text { in vacuo }\end{array} \\ \text { None } & 610 & - \\ \text { Copper sulphate } & 450 & 510 \\ \text { Chlorogenic acid } & 140 & 1060 \\ \text { Copper sulphate }+ & 50 & 660 \\ \text { chlorogenic acid } & & \end{array}$

When leaf extracts are made, CMV seems to be inactivated while polyphenols are being oxidized, and not by brown pigments formed as end-products of the reaction (Harrison \& Pierpoint, 1963). Table 4 shows that this is also true when CMV is inactivated by chlorogenic acid + copper. Chlorogenic acid was pre-incubated for different times with polyphenoloxidase-containing extracts of healthy leaves before incubation with infective extracts. The longer the period of pre-incubation, the less virus was inactivated. On incubating mixtures of pre-incubated preparations and virus with DIECA added and air excluded (conditions which prevent further oxidative reactions) CMV was inactivated only very slightly even by the preparation that had been pre-incubated for the shortest period. This slight inactivation may be caused by accumulation of virus-inactivating compounds in the early stages of the oxidation, but little importance can be attached to differences of infectivity of this degree. Neither bovine plasma albumin $(0 \cdot 1-1 \cdot 0 \%, \mathrm{w} / \mathrm{v})$ nor polyvinylpyrrolidone (PVP), two substances likely to absorb oxidized or unoxidized poly- 
phenols, protected CMV from inactivation during the oxidation of chlorogenic acid. PVP did not preserve infectivity when added to the extraction medium (Harrison \& Pierpoint, 1963).

\section{Table 4. Effect of oxidized chlorogenic acid on $C M V$}

Samples (2 ml.) of an extract of uninfetced tobacco leaves were incubated for various times in $4.75 \mathrm{ml}$. of solution containing tris buffer (85 mM), copper sulphate $(0.42 \mathrm{~mm})$ and chlorogenic acid $(5.0 \mathrm{~mm})$. After this incubation they were added to $5 \mathrm{ml}$. samples of an infective extract and kept at room temperature $\left(19^{\circ}\right)$ for $90 \mathrm{~min}$. either without further treatment or after adding DIECA (final concentration $1.03 \mathrm{~mm}$ ) and removing air. All the samples were dialysed overnight at $2^{\circ}$ before assaying their infectivity. Suitable controls showed that infectivity was not affected by adding DIECA and removing air.

\begin{tabular}{|c|c|c|}
\hline \multirow{3}{*}{$\begin{array}{c}\text { Pre-incubation of } \\
\text { extracts of } \\
\text { uninfected } \\
\text { leaves }\end{array}$} & \multicolumn{2}{|c|}{$\begin{array}{l}\text { Conditions of incubation } \\
\text { with infective extracts }\end{array}$} \\
\hline & \multirow{2}{*}{\multicolumn{2}{|c|}{$\begin{array}{c}\text { with D } \\
\text { No. lesions }\end{array}$}} \\
\hline & & \\
\hline 4 hr. at $37^{\circ}$ & 3750 & 4360 \\
\hline 2 hr. at $19^{\circ}$ & $\mathbf{3 1 2 0}$ & 4500 \\
\hline $1 \mathrm{hr}$. at $19^{\circ}$ & 1170 & 4400 \\
\hline $0.3 \mathrm{hr}$. at $19^{\circ}$ & 537 & 1570 \\
\hline $0 \mathrm{hr}$. & 291 & 2830 \\
\hline
\end{tabular}

\section{Table 5. Effect of polyphenols on infective extracts}

Each tube had $9 \mathrm{ml}$. of solution containing $6 \mathrm{ml}$. of infective extract, tris buffer $(\mathrm{pH} 7$; $62 \mathrm{~mm}$ in Expt. 1 ; $35 \mathrm{~mm}$ in Expt. 2), polyphenols $(2 \cdot 4 \mathrm{mM})$ and copper sulphate $(0 \cdot 29 \mathrm{~mm})$ as indicated. The solutions were kept at $18^{\circ}$ for $3 \mathrm{hr}$., dialysed overnight at $2^{\circ}$ and then assayed for infectivity.

\begin{tabular}{lcccr} 
Expt. 1 & \multicolumn{2}{c}{ Expt. 2 } \\
\multicolumn{1}{c}{ Substrate } & $\overbrace{\begin{array}{l}\text { Without With } \\
\text { copper }\end{array}}^{\text {copper }}$ & $\overbrace{\text { Without }}^{\text {copper }}$ & $\begin{array}{r}\text { With } \\
\text { copper }\end{array}$ \\
None & $\mathbf{5 4 3}$ & $\mathbf{3 7 0}$ & $\mathbf{1 6 0 5}$ & $\mathbf{1 5 3 5}$ \\
Chlorogenic acid & $\mathbf{3 5 8}$ & $\mathbf{5 4}$ & $\mathbf{1 4 0 0}$ & $\mathbf{5 6}$ \\
Caffeic acid & $\mathbf{5 5 0}$ & 62 & $\mathbf{1 5 9 4}$ & 4 \\
Catechol & $\mathbf{6 9 3}$ & $\mathbf{1 6 1}$ & $\mathbf{8 5 0}$ & 1100 \\
Gallic acid & $\mathbf{3 4 4}$ & 440 & - & -
\end{tabular}

\section{Inactivation of $C M V$ by other polyphenols}

Seven phenols, some of which occur in tobacco leaves (Roberts \& Wood, 1951) were incubated with CMV + copper; caffeic acid inactivated strongly and catechol slightly (Table 5), whereas quercetin, (+)-catechin, rutin, tyrosine and gallic acid were virtually ineffective. In a later section we show that none of the inactive polyphenols, except catechin, was appreciably oxidized by infective extracts; catechin was only slightly oxidized.

\section{Iron-dependent inactivation of $C M V$}

CMV was inactivated when incubated with iron salts and chlorogenic acid. Ferrous sulphate was as effective as ferric chloride, possibly because it oxidizes 
rapidly in solution. The minimum effective concentration of iron was about $0 \cdot 25 \mathrm{~mm}$ (Table 6). Zinc salts with chlorogenic acid did not inactivate. The iron-dependent inactivation has some properties in common with copper-dependent inactivation. The amount of inactivation increased with time; in one experiment infectivity was decreased by 40,70 and $96 \%$ after incubation at $22^{\circ}$ for 10,40 and $80 \mathrm{~min}$. Inactivation was largely prevented by adding DIECA (Table 6), or by removing air

Table 6. Effect of iron and chlorogenic acid on infective extracts

\begin{abstract}
Samples of infective extracts $\left(5 \mathrm{ml}\right.$.) were incubated for $2 \mathrm{hr}$. at $20^{\circ}$ with tris buffer (final concentration $49 \mathrm{mM} ; \mathrm{pH} 7 \cdot 0$ ) and the additions as indicated; the final volume was $8.2 \mathrm{ml}$. All solutions were then dialysed for $3 \mathrm{hr}$. at $2^{\circ}$ before being assayed for infectivity.
\end{abstract}

Additions

(final concentration, $\mathrm{mm}$ )

$\begin{array}{cccc}\begin{array}{c}\text { Chlorogenic } \\ \text { acid }\end{array} & \begin{array}{c}\text { Ferrous } \\ \text { sulphate }\end{array} & \text { DIECA } & \text { No. lesions } \\ 2 \cdot 6 & - & - & 1000 \\ - & 0 \cdot 25 & - & 1000 \\ 2 \cdot 6 & 0 \cdot 25 & 6 \cdot 1 & 703 \\ 2 \cdot 6 & 0 \cdot 25 & - & 49 \\ 2 \cdot 6 & 0 \cdot 025 & - & 363 \\ 2 \cdot 6 & 0 \cdot 0025 & - & 503 \\ 0 \cdot 29 & 0 \cdot 25 & - & 59 \\ 0 \cdot 29 & 0 \cdot 025 & - & 669\end{array}$

Table 7. Effect of air on the iron-dependent inactivation of $\mathrm{CMV}$

\begin{abstract}
Samples of infective extracts $(4 \mathrm{ml}$.) were added to solutions containing tris buffer (final concentration $36 \mathrm{~mm} ; \mathrm{pH} 7 \cdot 0$ ), chlorogenic acid $(2.7 \mathrm{~mm}$ ) and ferric chloride $(0.27 \mathrm{~mm})$ as indicated below; the final volume was $5.5 \mathrm{ml}$. After some flasks had been evacuated, they were all incubated at $22^{\circ}$ for $85 \mathrm{~min}$. DIECA (final concentration $6 \cdot 3 \mathrm{~mm}$ ) was then added to each and they were dialysed for $2.5 \mathrm{hr}$. at $2^{\circ}$ before being assayed for infectivity.
\end{abstract}

$\begin{array}{lrc}\begin{array}{c}\text { Additions } \\ \text { to incubation } \\ \text { mixture }\end{array} & \begin{array}{c}\begin{array}{c}\text { Incubated } \\ \text { aerobically }\end{array} \\ \text { None }\end{array} & \begin{array}{c}\text { Incubated } \\ \text { in vacuo }\end{array} \\ \text { Ferric chloride } & 1400 & - \\ \text { Chlorogenic acid } & \mathbf{6 3 6} & \mathbf{1 3 6 5} \\ \begin{array}{l}\text { Ferric chloride } \\ + \text { chlorogenic acid }\end{array} & \mathbf{1 5 1 5} & \mathbf{1 9 7 0} \\ \quad & 1302\end{array}$

(Table 7). Tobacco mosaic virus was not inactivated by this system or by the copperstimulated one. By contrast, nucleic acid prepared from tobacco mosaic virus is inactivated when incubated with iron alone (Bawden \& Pirie, 1959).

\title{
Polyphenoloxidase activity of infective extracts
}

The conversion of chlorogenic acid to a brown pigment by infective extracts incubated with copper was accompanied by absorption of oxygen (Table 8). Boiling the extracts for $10 \mathrm{~min}$. prevented browning and $\mathrm{O}_{2}$ uptake. The amount of oxygen absorbed in the reaction was almost $(86 \%)$ two atoms per molecule of chlorogenic acid present, a value suggested as a theoretical maximum for this oxidation (Rudkin 
$\&$ Nelson, 1947). Small amounts of carbon dioxide were evolved during the later stages of the reaction, giving a final R.Q. of about $\mathbf{0} \cdot \mathbf{2}$.

The rate at which chlorogenic acid was oxidized by most of the infective extracts was greatly decreased by omitting copper (Fig. 1). Oxidation was completely

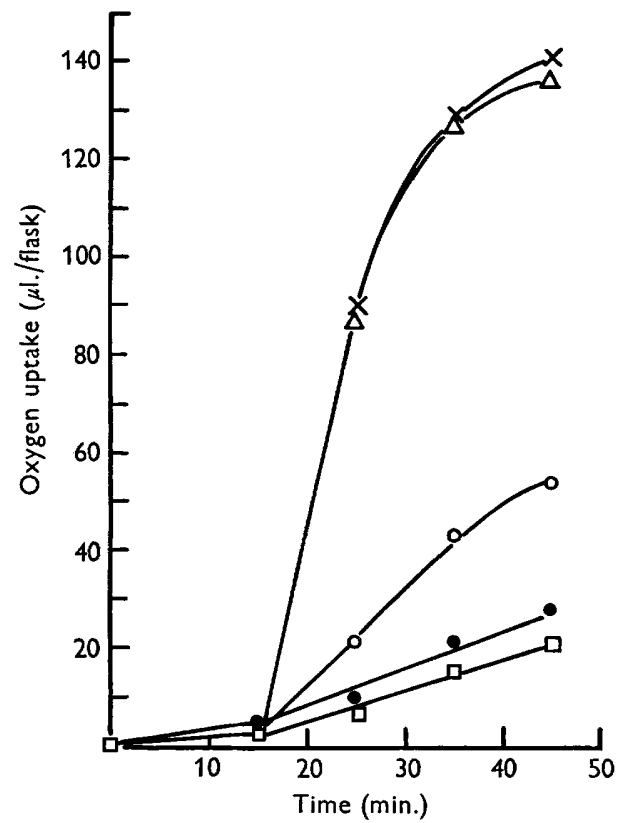

Fig. 1. Effect of copper sulphate on the oxidation of chlorogenic acid by infective extracts. The extract (1.5 ml.) was incubated in manometers with tris buffer (pH 7; final concentration $72 \mathrm{~mm}$ ) and copper sulphate at the following final concentrations: $360 \mu \mathrm{M}$ $(\times) ; 36 \mu \mathrm{M}(\triangle) ; 3.6 \mu \mathrm{M}(\bigcirc) ; 0.036 \mu \mathrm{M}(\bullet)$, none ( $\square$ ). After $15 \mathrm{~min}$., chlorogenic acid (final concentration $\mathbf{3 . 2} \mathrm{mm}$ ) was tipped in from the side arms. Oxygen uptake in the absence of leaf extract was negligible.

Table 8. Oxidation of chlorogenic acid by infective extracts

The extract was prepared in tris buffer $(0.2 \mathrm{M} ; \mathrm{pH} \mathrm{7.8)}$ containing DIECA (10 mM) and dialysed overnight at $2^{\circ}$. Manometric conditions were as described under Methods, and each flask contained tris buffer ( $\mathrm{pH} 7 ; 72 \mathrm{~mm}$ ) and, when specified, fresh or boiled leaf extract (1.5 ml.), chlorogenic acid (3.2 mM) and copper sulphate (0.36 $\mathrm{mm})$.

\begin{tabular}{clc} 
Extract & \multicolumn{1}{c}{ Additions } & $\begin{array}{c}\text { Oxygen } \\
\text { uptake } \\
(\mu \mathbf{l} \cdot / 30 \text { min. })\end{array}$ \\
Fresh & None & $\mathbf{4 \cdot 5}$ \\
Fresh & Copper sulphate & $\mathbf{5 \cdot 5}$ \\
Fresh & Chlorogenic acid & $\mathbf{5 \cdot 0}$ \\
Fresh & Copper sulphate + chlorogenic acid & $\mathbf{9 2 \cdot 0}$ \\
Boiled & Copper sulphate + chlorogenic acid & $\mathbf{3 \cdot 3}$ \\
None & Copper sulphate+ chlorogenic acid & $\mathbf{0}$
\end{tabular}

inhibited when DIECA (10 mM) was added with the copper. However, some preparations oxidized chlorogenic acid without added copper; this occurred with extracts made from the leaves of plants that had been infected with CMV for many weeks. Table 9 contrasts the effect of copper on extracts made from plants infected 
for different periods. The enzyme in extracts of leaves infected for 8 weeks recovered spontaneously from inhibition by DIECA; the reason is not clear.

Neither ferrous sulphate nor ferric chloride replaced copper sulphate in the oxidation of chlorogenic acid. In the experiment reported in Fig. 1, $360 \mu \mathrm{M}$ ferrous sulphate had as little effect on oxygen uptake of leaf extract + chlorogenic acid as did $0.036 \mu \mathrm{M}$ copper sulphate. Iron salts did not interfere with the oxidation that occurred when copper was added, even though highly coloured iron-chlorogenate complexes were formed.

Table 9. Effect of copper sulphate on the polyphenoloxidase extracted from tobacco leaves at different times after infection with $C M V$

Infective extracts were made from plants infected for different times and, after dialysing overnight at $\mathbf{2}^{\circ}$, were tested for ability to oxidize chlorogenic acid in the presence and absence of copper sulphate.

$\begin{array}{ccc}\begin{array}{c}\text { Time after } \\ \text { inoculating plants } \\ \text { (weeks) }\end{array} & \begin{array}{c}\text { With } \\ \text { copper } \\ \text { sulphate }\end{array} & \begin{array}{c}\text { Oxygen uptake } \\ (\mu \mathrm{l} . / 30 \text { min. }) \\ \text { copper } \\ \text { sulphate }\end{array} \\ \mathbf{2 . 5} & 146 & 24 \\ \mathbf{5} & 180 & 62 \\ 8 & 186 & 162\end{array}$

The rate at which chlorogenic acid was oxidized (Table 10) and the amount of oxygen absorbed depended on $\mathrm{pH}$ value and were greatest near $\mathrm{pH} 7$. Above $\mathrm{pH} 8$ chlorogenic acid oxidizes spontaneously without requiring added copper.

The polyphenoloxidase in extracts of infected leaves and in acetone powders of uninfected tobacco leaves (Reid, 1956; Clayton, 1959) have similar specificities. Of the phenols tested only caffeic acid and chlorogenic acid were oxidized rapidly (Table 11). Catechol and catechin were also oxidized, but more slowly. Usually rutin, tyrosine and quercetin were not oxidized, but gave small oxygen uptakes with some infective extracts. Gallic acid oxidized non-enzymically in the presence of copper; leaf extracts slightly diminished this reaction. Phenols extracted from CMV-infected leaves were also oxidized by the polyphenoloxidase. A methanol extract, made as described by Harrison \& Pierpoint (1963), absorbed rather more oxygen $(77 \mu \mathrm{l} . / 0 \cdot 1 \mathrm{ml}$.) than was expected ( $55 \mu \mathrm{l} . / 0 \cdot 1 \mathrm{ml}$.) from its estimated chlorogenic acid content.

\section{Inhibition of tobacco leaf polyphenoloxidase}

Harrison \& Pierpoint (1963) judged the effectiveness of polyphenoloxidase inhibitors by their ability to prevent the extracts becoming brown during disruption of the leaves. Substances that prevent browning also affect oxygen uptake when chlorogenic acid is incubated with infective leaf extracts. Extracts of infected leaves, prepared in tris buffer $(0 \cdot 2 \mathrm{M} ; \mathrm{pH} 7 \cdot 8)$ without DIECA, oxidized chlorogenic acid at rates similar to that shown in Table 8 , and the reaction did not depend on added copper. DIECA (10 $\mathrm{mm}$ ) inhibited this oxidation by $85-90 \%$, and prevented the browning. Although potassium ethylxanthate (10 $\mathrm{mm}$ ) decreased oxygen uptake by only half $(37-56 \%)$, it completely prevented the browning. At the same 
concentration, 2,9-dimethyl-1,10-phenanthroline decreased oxygen uptake by $15 \%$, and salicylaldoxime, EDTA, $p$-nitrophenol and sodium azide by less than $10 \%$. None of these compounds appreciably hindered the browning.

Table 10. Effect of $p H$ value on the polyphenoloxidase in infective extracts of leaves

The ability of an infective extract to oxidize chlorogenic acid was tested in the presence and absence of copper sulphate. The experimental conditions were as described under Methods except that the $\mathrm{pH}$ of the tris-HCl buffer was varied.

\begin{tabular}{ccc} 
& \multicolumn{2}{c}{$\begin{array}{c}\text { Oxygen uptake } \\
(\mu 1 . / 30 \text { min. })\end{array}$} \\
\cline { 2 - 3 } pH value & $\begin{array}{c}\text { Without } \\
\text { copper } \\
\text { sulphate }\end{array}$ & $\begin{array}{c}\text { With } \\
\text { copper } \\
\text { sulphate }\end{array}$ \\
6.0 & $1 \cdot 5$ & 64 \\
$7 \cdot 1$ & $\mathbf{3 \cdot 5}$ & 118 \\
$7 \cdot 7$ & 3 & 95 \\
$8 \cdot 1$ & 6 & 75 \\
8.9 & 16 & 56
\end{tabular}

Table 11. Oxidation of polyphenols by infective extracts

Each substrate, dissolved or suspended at pH 7, was tested manometrically alone, in the presence of copper sulphate, and in the presence of both copper sulphate and the leaf extracts. Conditions were as described under Methods. Oxygen uptake in the absence of substrate was negligible.

$\begin{array}{lrrr} & \text { Alone } & \begin{array}{c}\text { With } \\ \text { copper } \\ \text { sulphate }\end{array} & \begin{array}{c}\text { With } \\ \text { copper sulphate } \\ \text { and infective } \\ \text { extract }\end{array} \\ \text { Substrate (3.2 mM) } & - & - & 164 \\ \text { Chlorogenic acid } & 3 & 10 & 161 \\ \text { Catechol } & 3 & 11 & 32 \\ \text { (+)-Catechin } & 0 & 13 & 30 \\ \text { Gallic acid } & 10 & 39 & 30 \\ \text { Quercetin } & \mathbf{3} & 4 & 3 \\ \text { Rutin } & - & 0 & 0 \\ \text { L-Tyrosine } & 0 & 0 & 1\end{array}$

\section{DISCUSSION}

The properties of polyphenoloxidase explain three features of the copperdependent virus inactivating system. First, the compounds most effective in preserving infectivity when CMV is extracted from leaves, namely DIECA and potassium ethylxanthate, are those which most strongly inhibit the enzyme. Secondly, the polyphenols that inactivate CMV most in vitro, namely chlorogenic acid and caffeic acid, are those most rapidly oxidized. Thirdly, the minimum concentration of copper necessary to permit inactivation of CMV in vitro is about that required to reactivate the DIECA-treated polyphenoloxidase. The variable copper requirement of the inactivating system is partly explained by the fact that extracts of older leaves contain polyphenoloxidase which recovers spontaneously from inhibition by DIECA (Table 9). However, virus-inactivation experiments with extracts 
from leaves of different ages showed that other factors must also be involved. The amount of inactivation without copper probably depends not only on the extent to which the polyphenoloxidase is active without added copper, but also on the amounts of polyphenoloxidase and CMV in the extracts. Whether or not it occurs in a particular experiment also depends on how long the samples are incubated (Table 2).

Some polyphenoloxidases are known to contain copper (Mallette, 1950), and the inhibition of tobacco leaf polyphenoloxidase by DIECA suggests that it does also. This inhibition might be caused by removal of copper from the enzyme protein, or by the formation of an inactive protein-copper-DIECA complex. Unpublished work by Miss P. M. Bell supports the idea that copper is removed, but has not explained the difference (Table 9 ) between the enzyme in extracts made from leaves infected for different periods. The Michaelis constant of the enzyme in extracts made from leaves which have been infected for 4 weeks is similar to that in extracts from leaves which have been infected for 12 weeks; so is the inhibition constant $\left(K_{i}\right)$ with DIECA. Old leaves contain 2-3 times as much copper as young leaves, but so far there is no evidence that these small amounts of copper affect the inhibition of polyphenoloxidase by DIECA.

Tobacco necrosis virus and the nucleic acid prepared from tobacco mosaic virus are inactivated by a range of oxidation systems, some of them enzymic (Bawden \& Pirie, 1957, 1959). These oxidations, as well as the oxidation of chlorogenic acid, possibly produce a similar virus inactivating substance, perhaps some form of 'activated' oxygen. However, potassium ethylxanthate preserves the infectivity of CMV when leaves are disrupted, but it only partially inhibits the oxygen absorbing reactions. Thus it seems more probable that CMV is inactivated by a quinone intermediate or an end-product of the oxidation of chlorogenic acid. By analogy with the oxidation of other polyphenols, the initial oxidation product of chlorogenic acid may be a quinone, formation of one molecule of which involves the uptake of one atom of oxygen. A series of oxidation-reduction reactions may then convert half of this quinone to a hydroxyquinone, and regenerate chlorogenic acid from the rest. The hydroxyquinone probably polymerizes, partly by non-enzymic reactions, to produce the dark brown substance and some carbon dioxide. Either the intermediate quinones or the high molecular weight polymers may be responsible for inactivating CMV. Quinones react readily with amino acids and with other nitrogen and sulphur containing compounds; and reactions between polymerized polyphenols and proteins of leaves are suggested by the discovery that the brown compounds of large molecular weight extracted from dried tobacco leaves contain chlorogenic acid, rutin and amino acid residues (Jacobson, 1961).

A possible explanation of the results of the experiment in which chlorogenic acid was incubated with a leaf extract containing polyphenoloxidase and CMV then added (Table 4) is that the virus is inactivated by intermediates of the oxidation. Hampton \& Fulton (1961) concluded that $o$-quinone, produced during the oxidation of catechol, was responsible for inactivating prune dwarf and sour cherry necrotic ringspot viruses. However, the idea that the quinone formed from chlorogenic acid inactivates CMV is not easily reconciled with the fact that potassium ethylxanthate preserves the infectivity of CMV during extraction from tobacco leaves; this compound halves the amount of oxygen absorbed during the oxidation of chlorogenic acid, suggesting that it does not inhibit the formation of quinone, but a later stage 
in the oxidation. Nor can an effect of the brown end-products of the oxidation on CMV be excluded. These may have been ineffective in the experiment described in Table 4 because they combined with other proteins before CMV was added.

Although the oxidation products of chlorogenic acid probably act on the protein of $\mathrm{CMV}$, it is also possible that they react with its nucleic acid; this reaction might be responsible for loss of infectivity. A few experiments were made to explore this possibility, but the results are difficult to interpret. In one, samples of an infective extract, taken before and after incubation with chlorogenic acid and copper, were extracted with phenol in a manner likely to produce infective nucleic acid (Gierer \& Schramm, 1956). Both phenol extracts contained similar proportions (10\%) of the infectivity of the initial samples, suggesting that infective nucleic acid cannot be extracted from inactivated virus. This may indicate that oxidized chlorogenic acid affects virus nucleic acid, or that it strengthens the attachment of virus protein to unaltered nucleic acid. In work with prune dwarf virus, Hampton \& Fulton (1961) found that virus inactivated by $o$-quinone still appeared morphologically normal in the electron microscope and retained its ability to react with specific antiserum, suggesting that the surface protein of the inactivated virus had not been grossly altered.

Iron forms at least three complexes with chlorogenic acid (Hughes \& Swain, 1962), and between $\mathrm{pH} 7$ and 8 the predominant ones are ferric di- and tri-chlorogenate; whether or how these compounds inactivate CMV is unknown. The inactivation of CMV which occurred with iron, like that involving polyphenoloxidase, requires air and is prevented by DIECA. But iron, unlike copper, does not reactivate the DIECA-inhibited enzyme in leaf extracts. To confirm that there are two separate and unrelated inactivation processes, it will be necessary to show that inactivation by iron +chlorogenic acid occurs in virus preparations free from polyphenoloxidase.

The formation of iron complexes does not prevent the enzymic oxidation of chlorogenic acid. Two inactivating processes may therefore be operating when CMV-infected leaves are disrupted in the absence of DIECA, and it is of interest to estimate the relative effectiveness of the two. The iron contents of extracts made from infected leaves ( $1 \mathrm{~g}$. in $5 \mathrm{ml}$. tris buffer) ranged between 2.5 and $6 \cdot 4 \mu \mathrm{M}$. Inactivation was not detected in the experiment described in Table 6 with $25 \mu \mathrm{M}$ iron. Any effect of ferric chlorogenates on CMV in extracts made by grinding $1 \mathrm{~g}$. leaf in 4-5 ml. of liquid will therefore be confined to the period of leaf disintegration, when transitory high concentrations may occur. This inactivation effect will be diminished by iron-sequestering agents from the leaves (e.g. citrate), and will probably be small compared to the inactivation brought about by the enzymic oxidation of polyphenols.

We thank Miss S. Burnett for the metal determinations.

\section{REFERENCES}

Bawden, F. C. \& Pirie, N. W. (1957). A virus-inactivating system from tobacco leaves. J. gen. Microbiol. 16, 696.

Bawden, F. C. \& Pirie, N. W. (1959). The infectivity and inactivation of nucleic acid preparations from tobacco mosaic virus. J. gen. Microbiol. 21, 438.

Clayton, R. A. (1959). Properties of tobacco polyphenol oxidase. Arch. Biochem. Biophys. 81,404 . 
Gierer, A. \& Schramm, G. (1956). Infectivity of ribonucleic acid from tobacco mosaic virus. Nature, Lond. 177, 702.

Hampton, R. E. \& Fulton, R. W. (1961). The relation of polyphenol oxidase to instability in vitro of prune dwarf and sour cherry necrotic ringspot viruses. Virology, 13, 44.

Harrison, B. D. \& Pierpoint, W. S. (1963). The relation of polyphenoloxidase in leaf extracts to the instability of cucumber mosaic and other plant viruses. J. gen. Microbiol. 32, 417 .

Hughes, J. C. \& Swain, T. (1962). After-cooking blackening in potatoes. III. Examination of the interaction of factors by in vitro experiments. J. Sci. Fd Agric. 13, 358.

JAcobson, J. S. (1961). The brown pigments of autolysed tobacco leaves. I. Isolation and characterization. Arch. Biochem. Biophys. 93, 580.

MaLletTe, M. F. (1950). The nature of the copper enzymes involved in tyrosine oxidation. In Copper Metabolism, p. 48. Ed. by McElroy, W. D. and Glass, B. Baltimore: The Johns Hopkins Press.

REID, W. W. (1956). The polyphenols and polyphenolase of tobacco. J. Soc. Leath. Tr. Chem. p. 67.

Roberts, E. A. H. \& Woop, D. J. (1951). The polyphenols and amino acids of tobacco leaf. Arch. Biochem. Biophys. 33, 299.

Rudkin, G. O. \& Nelson, J. M. (1947). Chlorogenic acid and respiration of sweet potatoes. J. Amer. Chem. Soc. 69, 1470.

Umbreit, W. W., Burris, R. H. \& Stauffer, J. F. (1957). Manometric techniques and tissue metabolism. Minneapolis: Burgess Publishing Co. 